\title{
PENINGKATAN KOMPETENSI GURU DALAM MENYUSUN RENCANA PEMBELAJARAN MELALUI SUPERVI DIREKTIFDI SD NEGERI 01 SITUJUAH BATUAH
}

\author{
Syofiati \\ SD Negeri 01 Situjuah Batua,Kecamatan Situjuah Limo Nagari, Kabupaten Lima Puluh Kota \\ email: syofiatievi67048@gmail.com
}

\begin{abstract}
The main purpose of this school action research is to improve the pedagogical competence of teachers at SD Negeri 01 Situjuah Batua, who do not understand enough in compiling lesson plans that are in accordance with the competency standards of each lesson so that they can be a reference in the learning process so that students are able to achieve minimum completeness criteria.The form of this research is School Action Research which consists of 4 stages, namely planning, implementing action, observing, and reflecting. The subjects were teachers at SD Negeri 01 Situjuah Batua, Situjuah Limo Nagari District, Lima Puluh Kota Regency.Based on the results of this school action research, it can be taken from the component of the formulation of learning objective indicators, seen an increase from $40 \%$ in initial ability, to $60 \%$ in cycle 1 and increasing to $70 \%$ at the end of the activity. ability from $65 \%$ to $70 \%$ after cycle 1 and further strengthened to $80 \%$. In the Strategy Selection Component and method learning, there was a significant increase from the original only $40 \%$ to $60 \%$ in cycle 1 and increased again to $75 \%$ after the cycle 2.
\end{abstract}

Keywords: Pedagogic Competence, RPP, Directive Supervision

\begin{abstract}
ABSTRAK
Tujuan utama dari penelitian tindakan sekolah ini adalah untuk membantu meningkatkan kompetensi paedagogik guru guru di SD Negeri 01 Situjuah Batua, yang kurang memahami dalam menyusun rencana pembelajaran yang sesuai dengan standar kompetensi masing- masing pelajaran agar dapat menjadi acuan dalam proses pembelajaran sehingga peserta didik mampu mencapai kriteria ketuntasan minimal.Bentuk penelitian ini adalah Penelitian Tindakan Sekolah yang terdiri dari 4 tahapanya itu perencanaan, pelaksanaan tindakan, observasi, dan refleksi. Sebagai subjek adalah guru- guru di SD Negeri 01 Situjuah Batua Kecamatan Situjuah Limo Nagari Kabupaten Limo Puluh Kota.Berdasarkan hasil penelitian tindakan sekolah ini dapat diambil kesimpulan pada komponen Perumusan indikator tujuan pembelajaran, terlihat peningkatan dari $40 \%$ pada kemampuan awal, menjadi $60 \%$ pada siklus 1 dan meningkat menjadi $70 \%$ pada akhir kegiatan.Pada Komponen Penentuan bahan dan materi pembelajaran, terdapat peningkatan kemampuan dari $65 \%$ menjadi $70 \%$ setelah siklus 1 dan lebih menguat menjadi 80\%.Dalam Komponen Pemilihan Strategi dan metoda pembelajaran, terlihat adanya peningkatan yang signifikan dari yang semula hanya $40 \%$ menjadi $60 \%$ pada siklus 1 dan meningkat lagi menjadi $75 \%$ setelah siklus 2 .
\end{abstract}

Kata kunci: Kompetensi Pedagogik, RPP, Supervisi Direktif 


\section{PENDAHULUAN}

Reformasi pendidikan tidak cukup hanya dengan perubahan dalam sektor kurikulum, baik struktur maupun prosedur penulisannya. Pembaharuan kurikulum akan lebih bermakna bila diikuti oleh perubahan praktik pembelajaran di dalam maupun di luar kelas. Keberhasilan implementasi kurikulum sangat dipengaruhi oleh kemampuan guru yang akan menerapkan dan mengaktualisasikan kurikulum tersebut. Tidak jarang kegagalan implementasi kurikulum disebabkan oleh kurangnya pengetahuan, keterampilan dan kemampuan guru dalam memahami tugas tugas yang harus dilaksanakannya. Hal itu berarti bahwa guru sebagai pelaksana kegiatan pembelajaran menjadi kunci atas keterlaksanaan kurikulum di sekolah.

Dalam kurikulum 2013, guru diberi kebebasan untuk menyusun strategi pembelajaran, mengubah, memodifikasi, bahkan membuat sendiri silabus yang sesuai dengan kondisi sekolah dan daerahnya, dan menjabarkannya menjadi persiapan mengajar yang siap dijadikan pedoman pembentukan kompetensi peserta didik.

Strategi pembelajaran sangat diperlukan dalam menunjang terwujudnya seluruh kompetensi yang dimuat dalam kurikulum 2013.Kurukulum memuat apa yang diajarkankepada pesrta didik, sedangkan pembelajaran merupakan bagaimana yang diajarkan dikuasai peserta didik. Konsep inilah yang dikemas dalam Rencana Pelaksanaan Pembelajaran (RPP) yang dikembangkan oleh pendidik yang mengacu pada silabus, seperangkat rencana yang menjadi pedoman pendidik dalam melaksanakan tahapan pembelajaran baik secara teori maupun praktek. Namun kenyataannya masih banyak guru yang belum mampu menyusun Rpp dengan baik dan sempurna.

Upaya perwujudan pengembangan silabus menjadi perencanaan pembelajaran yang implementatif memerlukan kemampuan yang komprehensif. Kemampuan itulah yang dapat mengantarkan guru menjadi tenaga yang professional. Guru yang professional harus memiliki 5 (lima) kompetensi yang salah satunya adalah kompetensi penyusunan rencana pembelajaran. Pembelajaran tampa perencanaan cendrung mengalami kegagalan karena tidak memiliki acuan apa yang dilakukan dalam memcapai keberhasilan pembelajaran.

Suatu hal yang tidak dapat ditawar bahwa RPP wajib dibuat oleh pendidik dengan model pembelajaran yang memilki komponen yang menyusun RPP. Pendidik mengembangkan dan menjabarkan kompetensi dasar kedalam indikator pencapaian komptensi serta tujuan pembelajaran. Namun dalam kenyataannya masih banyak guru yang belum mampu menyusun rencana pembelajaran sehingga hal ini secara otomatis berimbas pada kualitas out put yang dihasilkan dalam proses pembelajaran.

Salah satu program yang dapat dilaksanakan dalam rangka penembangan kompetensi guru dalam menyusun Rencana pembelajaran adalah melalalui supervisi akademik karena prinsipnya tujuan supervisi akademik adalah untuk membantu guru mengembangkan kemampuannya mengelolah proses pembelajaran demi tercapainya tujuan akademik. Dan secara spesifiknya supervisi yang cara pendekatan lansung terhadap masalah yang dihadapi guru-guru adalah supervisi direktif (Muhammad Fathurrahman, 2012). Supervisi direktif ini menuntut supervisor banyak bicara dan berkomentar sehingga guru-guru dituntut untuk bisa berbuat dan melakukan pekerjaan dengan benar. Menurut Afrijawidia 
(2017:329) Pendekatan direktif bertujuan agar guru yang mengalami masalah perlu diberi ransangan agar ia bisa bereaksi.

Tujuan dari dilaksanakannya penelitian tindakan sekolah ini adalah :

1. Untuk mengetahui perencanaan supervisidirektif di sekolah dapat meningkatkan kompetensi pedagogik guru dalam menyususn RPP di SD Negeri 01 Situjuah Batua.

2. Untuk mengetahui pelaksanaan supervisidirektif di sekolah dapat meningkatkan kompetensi pedagogik guru dalam menyususn RPP di SD Negeri 01 Situjuah Batua.

3. Untuk mengetahui hasil supervisidirektif di sekolah dapat meningkatkan kompetensi pedagogik guru dalam menyususn RPP di SD Negeri 01 Situjuah Batua.

\section{METODOLOGI}

Jenis penelitian ini merupakan Penelitian Tindakan Sekolah (PTS). Penulis PTS di SDN 01 Situjuah Batua Kecamatan Situjuah Limo Nagari Kabupaten Lima Puluh Kota Tahun Pelajaran 2019/2020. Penulis menentukan subyek penelitian yaitu 12 orang guru di SDN 01 Situjuah Batua Kecamatan Situjuah Limo Nagari Kabupaten Lima Puluh Kota tahun pelajaran 2019/2020. Penelitian ini dilaksanakan pada bulan Agustus s/d Oktober 2019 tahun pelajaran 2019/2020.

Langkah-langkah PTS yaitu: perencanaan, pelaksanaan, pengamatan, dan refleksi. Langkah-langkah PTS seperti berikut:

\section{Siklus 1}

\section{a. Perencanaan}

Penelitian tindakan ini melibatkan 12 orang guru kelas, kegiatan ini dilakukan selama Agustus sampai Oktober, dan dilakukan di sekolah dengan pengaturan waktu yang lebih fleksibel sehingga tidak mengganggu jadwal kegiatan pembelajaran. Sarana yang digunakan dalam kegiatan ini adalah silabus yang telah disusun bersama oleh setiap kelompok guru mata pelajaran dan Rencana Pelaksanaan Pembelajaran (RPP) yang disusun sendiri oleh guru yang bersangkutan sesuai dengan Standar kompetensi dan Kompetensi dasar pada masing-masing mata pelajaran. RPP inilah yang menjadi bahan acuan untuk menentukan materi pembinaan terhadap masing-masing guru, dan sekaligus menjadi alat ukur keberhasilan penelitian. Kegiatan ini dilakukan dalam dua siklus hingga guru dinilai memiliki kemampuan untuk menyusun perencanaan pembelajaran yang baik. Dalam setiap siklus supervisor melakukan observasi dan penilaian terhadap perkembangan kemampuan setiap guru.

b. Tindakan dan pengamatan

Penelitian diawali dengan cara menyerahkan rencana pembelajaran yang disusun sendiri sesuai dengan mata pelajaran dan standar kompetensi masing masing kepada supervisor. Berdasarkan data tersebut supervisor melakukan pembinaan kepada guru sesuai dengan kesulitan masing masing guru.

Dalam menyusun RPP guru harus mencantumkan Standar Kompetensi yang memayungi Kompetensi Dasar yang akan disusun dalam RPP-nya. Di dalam RPP secara rinci harus dimuat tujuan pembelajaran,materi pembelajaran, metode pembelajaran, langkah-langkah kegiatan pembelajaran, sumber belajar, 
dan penilaian. Guru menyusun RPP dengan mengikuti langkah-langkah sebagai berikut:

Langkah-langkah Penyusunan Rencana Pelaksanaan Pembelajaran (RPP)

1) Mencantumkan Identitas

Nama sekolah, mata pelajaran, kelas/semester, standar kompetensi, kompetensi dasar, indikator, dan alokasi waktu. Dalam penyusunannya RPP disusun untuk satu kompetensi dasar, standar kompetensi, kompetensi dasar, dan indikator dikutip dari silabus yang disusun oleh satuan pendidikan, dan alokasi waktu diperhitungkan untuk pencapaian satu kompetensi dasar yang bersangkutan, yang dinyatakan dalam jam pelajaran dan banyaknya pertemuan. Oleh karena itu, waktu untuk mencapai suatu kompetensi dasar dapat diperhitungkan dalam satu atau beberapa kali pertemuan bergantung pada karakteristik kompetensi dasarnya.

2) Mencantumkan Tujuan Pembelajaran

Tujuan Pembelajaran berisi penguasaan kompetensi yang operasional yang ditargetkan/dicapai dalam rencana pelaksanaan pembelajaran. Tujuan pembelajaran dirumuskan dalam bentuk pernyataan yang operasional dari kompetensi dasar. Apabila rumusan kompetensi dasar sudah operasional, rumusan tersebutlah yang dijadikan dasar dalam merumuskan tujuan pembelajaran. Tujuan pembelajaran dapat terdiri atas sebuah tujuan atau beberapa tujuan.

3) Mencantumkan Materi Pembelajaran

Materi pembelajaran adalah materi yang digunakan untuk mencapai tujuan pembelajaran. Materi pembelajaran dikembangkan dengan mengacu pada materi pokok yang ada dalam silabus.

4) Mencantumkan Metode Pembelajaran

Metode dapat diartikan benar-benar sebagai metode, tetapi dapat pula diartikan sebagai model atau pendekatan pembelajaran, bergantung pada karakteristik pendekatan dan/atau strategi yang dipilih.

5) Mencantumkan Langkah-langkah Kegiatan Pembelajaran

Untuk mencapai suatu kompetensi dasar harus dicantumkan langkahlangkah kegiatan setiap pertemuan. Pada dasarnya, langkah-langkah kegiatan memuat unsur kegiatan pendahuluan/pembuka, kegiatan inti, dan kegiatan penutup. Akan tetapi, dimungkinkan dalam seluruh rangkaian kegiatan, sesuai dengan karakteristik model yang dipilih, menggunakan urutan sintaks sesuai dengan modelnya. Oleh karena itu, kegiatan pendahuluan/pembuka, kegiatan inti, dan kegiatan penutup tidak harus ada dalam setiap pertemuan.

6) Mencantumkan Sumber Belajar

Pemilihan sumber belajar mengacu pada perumusan yang ada dalam silabus yang dikembangkan oleh satuan pendidikan. Sumber belajar mencakup sumber rujukan, lingkungan, media, narasumber, alat, dan bahan. Sumber belajar dituliskan secara lebih operasional. Misalnya, sumber belajar dalam silabus dituliskan buku referensi, dalam RPP harus dicantumkan judul buku teks tersebut, pengarang, dan halaman yang diacu.

7) Mencantumkan Penilaian

Penilaian dijabarkan atas teknik penilaian, bentuk instrumen, dan instrumen yang dipakai untuk mengumpulkan data. Dalam sajiannya dapat ituangkan dalam bentuk matrik horisontal atau vertikal. Apabila penilaian 
menggunakan teknik tes tertulis uraian, tes unjuk kerja, dan tugas rumah yang berupa proyek harus disertai rubrik penilaian.

\section{c. Refleksi}

Dalam kegiatan refleksi ini, Pembina/supervisor bersama dengan guruguru melakukan diskusi tentang unsur-unsur RPP dan langkah langkah kegiatan penyusunan dan pengembangannya. Dalam kegiatan ini juga dibicarakan berbagai permasalahan yang dirasakan oleh para guru termasuk kendala serta manfaat yang dirasakan terhadap perubahan kemampuan mereka dalam penyusunan RPP. Hasil yang diperoleh dari kegiatan refleksi ini akan dijadikan sebagai bahan perencanaan dan tindakan yang akan dilakukan pada siklus berikutnya.

Analisa data yang digunakan dalam penelitian ini adalah analisa data kualitatif yang bersumber dari data primer maupun empiris. Melalui analisa data ini dapat diketahui ada tidaknya peningkatan kinerja dan kompetensi guru kelas.

Teknik pengumpulan data dari penelitian tindakan sekolah ini adalah melalui data kualitatif yang diperoleh dari hasil tes, observasi, maupun pengamatan.Alat pengumpulan data dalam PTS ini menggunakan instrumen supervisi, menggunakan hasil penyusun RPP, dan menggunakan lembar observasi

\section{Siklus 2}

Kegiatan Perencanaan berdasarkan pada refleksi dari siklus 1, sementara untuk langkah-langkah kegiatan tindakan dan pengamatan sama dengan siklus 1 dengan memperhatikan prioritas permasalahan yang disimpulkan pada siklus 1 dan dilanjutkan dengan kegiatan refleksi. Apabila hasil refleksi pada siklus 2 sudah menunjukan adanya peningkatan kemampuan guru secara signifikan, maka kegiatan penelitian dianggap berhasil, tetapi sebaliknya apabila belum menunjukan hasil yang di harapkan, maka kegiatan penelitian akan dilanjutkan dengan siklus berikutnya dengan langkah-langkah kegiatan yang sama dengan kegiatan pada siklus 2 ini.

\section{Analisis Data}

Analisa data yang digunakan dalam penelitian ini adalah analisa data kualitatif yang bersumber dari data primer maupun empiris. Melalui analisa data ini dapat diketahui ada tidaknya peningkatan kinerja dan kompetensi guru kelas.

Teknik pengumpulan data dari penelitian tindakan sekolah ini adalah melalui data kualitatif yang diperoleh dari hasil tes, observasi, maupun pengamatan.Alat pengumpulan data dalam PTS ini menggunakan instrumen supervisi, menggunakan hasil penyusun RPP, dan menggunakan lembar observasi

Kegiatan observasi dilaksanakan bersamaan dengan pelaksanaan tindakan yaitu pada saat diskusi. Tahap observasi bertujuan untuk mengetahui kerjasama, kreativitas, perhatian, maupun presentasi yang dilakukan guru dalam menyusun skenario pembelajaran maupun dalam melaksanakan pembelajaran dengan memanfaatkan lingkungan sekolah sebagai sumberbelajar.

Pelaksanaan observasi dilakukan dengan menggunakan lembar observasi yang dapat dilihat pada Tabel 1. 
Tabel 1. Instrumen Penelitian

\begin{tabular}{|c|c|c|c|c|c|c|}
\hline \multirow{3}{*}{ NO } & \multirow{3}{*}{ ASPEK } & \multirow{3}{*}{ INDIKATOR } & \multicolumn{3}{|c|}{ Hasil Penelaahan } & \multirow{3}{*}{ Ket } \\
\hline & & & 3 & 2 & 1 & \\
\hline & & & Lengkan & Kurang & Tidak & \\
\hline \multirow{13}{*}{$\mathrm{A}$} & \multirow{13}{*}{$\begin{array}{l}\text { Komponen } \\
\text { RPP }\end{array}$} & 1. Identitas mata pelajaran & & & & \\
\hline & & 2. Standar kompetensi & & & & \\
\hline & & 3. Kompetensi dasar & & & & \\
\hline & & 4. Indikator pencapaian & & & & \\
\hline & & 5. Tujuan pembelajaran & & & & \\
\hline & & 6. Materi ajar & & & & \\
\hline & & 7. Alokasi waktu & & & & \\
\hline & & 8. Metode pembelajaran & & & & \\
\hline & & $\begin{array}{l}\text { 9. Kegiatan Pembelajaran } \\
\text { (terdiridari }\end{array}$ & & & & \\
\hline & & 10.Penilaian hasil belajar & & & & \\
\hline & & $\begin{array}{l}\text { 11.Memuat nilai karakter } \\
\text { budaya bangsa }\end{array}$ & & & & \\
\hline & & 12.Sumber belajar & & & & \\
\hline & & 13.Disusun dalam bahasa & & & & \\
\hline & & & Sesuai & \begin{tabular}{|l} 
Sesuai \\
sebagian
\end{tabular} & $\begin{array}{l}\text { Tidak } \\
\text { sesuai }\end{array}$ & \\
\hline \multirow[t]{10}{*}{ B } & \multirow{10}{*}{$\begin{array}{l}\text { Keterkaitan } \\
\text { antar } \\
\text { Komponen } \\
\text { RPP dan } \\
\text { silabus }\end{array}$} & $\begin{array}{l}\text { 1. } \begin{array}{l}\text { Kesesuaian SK, KD } \\
\text { dengan }\end{array} \\
\end{array}$ & & & & \\
\hline & & $\begin{array}{l}\text { 2. Kesesuaian indikator } \\
\text { dengan tujuan }\end{array}$ & & & & \\
\hline & & $\begin{array}{l}\text { 3. Kesesuaian tujuan } \\
\text { pembelajaran dengan }\end{array}$ & & & & \\
\hline & & $\begin{array}{l}\text { 4. Keluasan dan kedalaman } \\
\text { materi disesuaikan } \\
\text { dengan karakteristik }\end{array}$ & & & & \\
\hline & & $\begin{array}{l}\text { 5. Keluasan dan kedalaman } \\
\text { materi memungkinkan } \\
\text { dicapai dalam waktu yang }\end{array}$ & & & & \\
\hline & & $\begin{array}{l}\text { 6. Kesesuaian metode } \\
\text { dengan tujuan dan materi }\end{array}$ & & & & \\
\hline & & $\begin{array}{l}\text { 7. Kesesuaian kegiatan } \\
\text { dengan metode }\end{array}$ & & & & \\
\hline & & $\begin{array}{l}\text { 8. Kesesuaian penilaian } \\
\text { dengan tujuan }\end{array}$ & & & & \\
\hline & & $\begin{array}{l}\text { 9. Kesesuaian buku ajar } \\
\text { dengan materi pelajaran }\end{array}$ & & & & \\
\hline & & $\begin{array}{l}\text { 10.Kesesuaian antara } \\
\text { komponen RPP yang }\end{array}$ & & & & \\
\hline & & & Layak & $\begin{array}{l}\text { Sebagian } \\
\text { layak }\end{array}$ & $\begin{array}{l}\text { Tidak } \\
\text { layak }\end{array}$ & \\
\hline
\end{tabular}




\begin{tabular}{|l|l|l|l|l|l|l|}
\hline C & \begin{tabular}{l} 
Kelayakan \\
kegiatan \\
\multirow{2}{*}{$\begin{array}{l}\text { pembela } \\
\text { jaran }\end{array}$}
\end{tabular} & 1. Kelayakan kegiatan & & & & \\
\hline & 2. Memuat kegiatan & & & & \\
\hline & 3. Memuat kegiatan & & & & \\
\hline & 4. Memuat kegiatan & & & & \\
\hline & 5. Kelayakan kegiatan & & & & \\
\hline
\end{tabular}

Rumus penilaiannya adalah $\quad N I L A I=\frac{\text { Skor Yang Diperoleh }}{84} \times 100$. Setelah diperoleh nilai, maka nilai tersebut ditransfer ke dalam bentuk kualitatif untuk memberikan komentar bagaimana kualitas sikap guru yang diamati dalam diskusi penyusunan skenario pembelajaran dan penilaian pelaksanaan pembelajaran dengan kriteria penilaian acuan patokan skala lima seperti terlihat pada Tabel 2 berikut:

Tabel 2. Kriteria Penilaian

\begin{tabular}{|c|c|}
\hline PERINGKAT & NILAI \\
\hline Amat Baik ( AB) & $90<\mathrm{AB} \leq 100$ \\
\hline Baik (B) & $80<\mathrm{B} \leq 90$ \\
\hline Ckup (C) & $70<\mathrm{C} \leq 80$ \\
\hline Kurang (K) & $\leq 70$ \\
\hline
\end{tabular}

Tahap evaluasi dilakukan pada akhir tindakan yang bertujuan untuk mengetahui tingkat kemampuan guru dalam menyusun RPP. Pelaksanaaan evaluasi dilakukan dengan menggunakan lembar pengamatan dengan format sesuai pada Tabel 3 berikut:

Tabel 3. Tabel Lembar Pengamatan

\begin{tabular}{|c|c|c|c|c|c|c|}
\hline \multirow{3}{*}{ No } & \multirow{3}{*}{$\begin{array}{c}\text { Karakteris } \\
\text { tik }\end{array}$} & \multirow{3}{*}{ Deskriptor } & \multicolumn{4}{|c|}{ Kualifikasi } \\
\hline & & & SB & B & $\mathrm{C}$ & $\mathbf{K}$ \\
\hline & & & 4 & 3 & 2 & 1 \\
\hline 1 & $\begin{array}{l}\text { Kejelasan } \\
\text { perumusan } \\
\text { tujuan } \\
\text { kegiatan }\end{array}$ & $\begin{array}{l}\text { a. Perumusan tujuan } \\
\text { b. Rumusan tujuan tidak menimbulkan } \\
\text { penafsiran ganda } \\
\text { c. Rumusan tujuan lengkap (memenuhi } \\
\mathrm{A}=\text { Audence, } \mathrm{B}=\text { Behavior, } \mathrm{C}= \\
\text { Condition, } \mathrm{D}=\text { Degree) } \\
\text { d. Rumusan tujuan berurutan secara } \\
\text { logis dari mudah ke sukar }\end{array}$ & & & & \\
\hline 2 & $\begin{array}{l}\text { Pemilihan } \\
\text { materi }\end{array}$ & $\begin{array}{l}\text { a. Materi sesuai dengan tujuan } \\
\text { pembelajaran } \\
\text { b. Pemilihan materi sesuai dengan } \\
\text { karakteristik guru } \\
\text { c. Pemilihan materi sesuai dengan } \\
\text { permasalahan yang dihadapi guru } \\
\text { d. Pemilihan materi sesuai dengan } \\
\text { bahan yang akan dijelaskan }\end{array}$ & & & & \\
\hline 3 & $\begin{array}{l}\text { Pengorganis } \\
\text { asian materi }\end{array}$ & $\begin{array}{l}\text { a. Cakupan materi luas } \\
\text { b. Materi sistematis } \\
\text { c. Sesuai dengan alokasi waktu }\end{array}$ & & & & \\
\hline
\end{tabular}




\begin{tabular}{|c|c|c|c|c|c|c|}
\hline \multirow{3}{*}{ No } & \multirow{3}{*}{$\begin{array}{c}\text { Karakteris } \\
\text { tik }\end{array}$} & \multirow{3}{*}{ Deskriptor } & \multicolumn{4}{|c|}{ Kualifikasi } \\
\hline & & & SB & B & $\mathbf{C}$ & $\mathbf{K}$ \\
\hline & & & 4 & 3 & 2 & 1 \\
\hline & & $\begin{array}{l}\text { d. Kemutakhiran (sesuai dengan } \\
\text { perkembangan terakhir bidangnya) }\end{array}$ & & & & \\
\hline 4 & $\begin{array}{l}\text { Pemilihan } \\
\text { sumber/ } \\
\text { materi }\end{array}$ & $\begin{array}{l}\text { a. Sesuai dengan tujuan pembelajaran } \\
\text { b. Sesuai dengan materi ajar } \\
\text { c. Sesuai dengan karakteristik peserta } \\
\text { didik } \\
\text { d. Sesuai dengan lingkungan }\end{array}$ & & & & \\
\hline 5 & $\begin{array}{l}\text { Kejelasan } \\
\text { proses }\end{array}$ & $\begin{array}{l}\text { a. Langkah-langkah berurut (awal, inti, } \\
\text { dan penutup) } \\
\text { b. Langkah-langkah sesuai dengan } \\
\text { alokasi waktu } \\
\text { c. Langkah-langkah sesuai dengan } \\
\text { materi ajar } \\
\text { d. Langkah-langkah jelas dan rinci }\end{array}$ & & & & \\
\hline 6 & $\begin{array}{l}\text { Teknik } \\
\text { akademik }\end{array}$ & $\begin{array}{l}\text { a. Teknik sesuai dengan tujuan } \\
\text { pelaksanaan } \\
\text { b. Teknik sesuai dengan karakteristik } \\
\text { dan kebutuhan guru } \\
\text { c. Teknik sesuai dengan kebutuhan } \\
\text { guru dan sekolah } \\
\text { d. Teknik sesuai dengan permasalahan } \\
\text { yang dihadapi guru }\end{array}$ & & & & \\
\hline 7 & $\begin{array}{l}\text { Kelengka } \\
\text { pan } \\
\text { instrumen }\end{array}$ & $\begin{array}{l}\text { a. Penilaian lengkap dan sesuai dengan } \\
\text { tujuan } \\
\text { b. Penilaian sesuai dengan tujuan } \\
\text { c. Penilaian lengkap dan jelas } \\
\text { d. Penilaian disertai pedoman } \\
\text { penskoran yang lengkap }\end{array}$ & & & & \\
\hline
\end{tabular}

Keterangan:

SB : Sangat Baik (4) jika keempat deskriptor pada masing-masing karakteristik dilakukan.

B : Baik (3) jika jika tiga dari keempat deskriptor pada masing-masing karakteristik dilakukan.

C : Cukup (2) jika dua dari keempat descriptor pada masing-masing karakteristik dilakukan

K : Kurang (1) jika satu dari keempar deskriptor pada masing-masing karakteristik dilakukan.

Lembar pengamatan dimaksudkan sebagai pedoman terperinci yang berisi langkah-langkah melakukan observasi mulai dari merumuskan masalah, kerangka teori untuk menjabarkan perilaku yang akan diobservasi, prosedur dan teknik perekaman, kriteria analisis hingga interpretasi. 


\section{HASIL PENELITIAN DAN PEMBAHASAN}

\section{Hasil Penelitian.}

Penelitian tindakan yang dilakukan di SD Negeri 01 Situjuah Batua ini dilakukan oleh penulis melalui tehnik supervisi akademik secara berkelompok sebagai upaya untuk meningkatkan kemampuan/kompetensi pedagogik guru dalam menyusun perencanaan pembelajaran di kelas. Penelitian dilakukan terhadap 12 orang guru kelas yang perlu dalam mengelola perencanaan dan pelaksanaan pembelajaran. Namun demikian permasalahan dalam penelitian tindakan ini difokuskan pada peningkatan kompetensi penyusunan Rencana Pelaksanaan Pembelajaran (RPP) dengan asumsi apabila guru sudah mampu menyusun RPP dengan baik, maka setidaknya dia sudah memiliki pedoman untuk melakukan langkah-langkah kegiatan pembelajaran di kelas sesuai dengan mata pelajaran masing-masing.

Kegiatan yang dilakukan dalam 2 siklus ini, dilakukan sejak bulan Agustus sampai bulan Oktober 2020 dengan menitikberatkan pada unsur-unsur dan langkah-langkah penyusunan RPP sebagaimana yang terlihat pada kegiatan tindakan penelitian yang telah diuraikan. Dari awal yang diperoleh pada kegiatan penelitian, terlihat bahwa $60 \%$ guru masih memiliki kesulitan dalam merumuskan indikator tujuan pembelajaran yang efektif sesuai dengan Standar Kompetensi dan Kompetensi Dasar masing-masing mata pelajaran. Selain itu guru juga masih menemukan kesulitan dalam memilih Strategi dan metode pembelajaran, serta menentukan teknik dan metode penilaian yang bisa mengukur pencapaian tujuan pembelajaran. Sementara untuk penentuan bahan belajar/ materi pembelajaran sudah dikuasai hingga $65 \%$ dan media yang direncanakan sudah $60 \%$ sesuai. Namun dalam penentuan kegiatan pembelajaran belum terinci langkah-langkah dan alokasi waktu yang dibutuhkan. Di bawah ini dapat kita lihat pada grafik 1 kemampuan guru pada awal kegiatan :

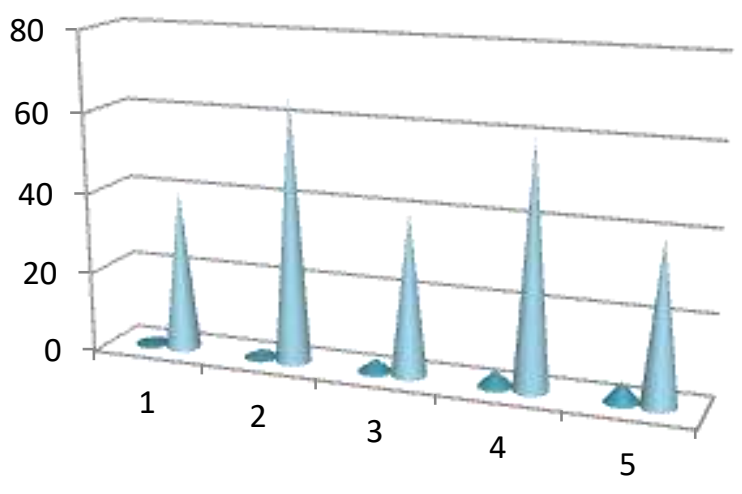

\section{Grafik 1. Kemampuan Guru dalam Penyusunan RPP}

Berdasarkan pada data tersebut, maka dilakukan tindakan pada siklus 1 dengan titik berat pada kesulitan-kesulitan yang dihadapi, dengan cara memberikan penjelasan contoh-contoh yang relevan. Pada akhir kegiatan siklus 1 diperoleh peningkatan kemampuan guru sebagai berikut: Pada perumusan indikator tujuan pembelajaran sudah ada peningkatan hingga mencapai $60 \%$, Penentuan Bahan/materi pelajaran tetap pada 70\%,Kemampuan menentukan Strategi/metode Pembelajaran yang relevan meningkat menjadi $60 \%$, Perencanaan penggunaan media pembelajaran pada level $60 \%$ tetapi ada peningkatan pada variasi media yang digunakan, dan dalam penentuan rencana 
evaluasi pembelajaran juga mengalami peningkatan hingga 60\% dan sudah terlihat gambaran bentuk dan jenis evaluasi yang digunakan. Peningkatan hasil setelah siklus 1 dapat dilihat pada grafik 2:

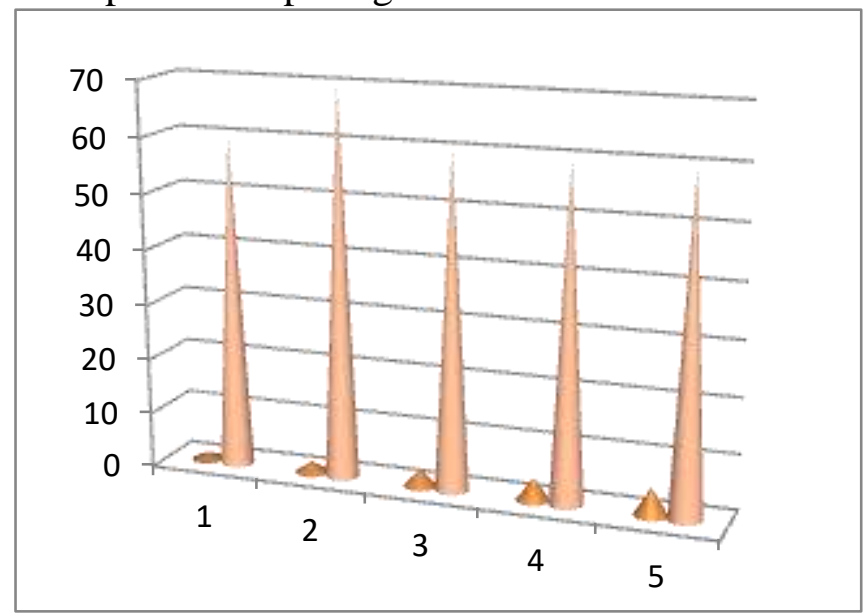

\section{Grafik 2. Kemampuan Perencanaan Pembelajaran Setelah Siklus 1}

Melihat hasil yang diperoleh pada refleksi kegiatan siklus 1, maka dilakukan tindakan penelitian pada siklus 2 dengan menggunakan hasil tindakan siklus 1 sebagai bahan masukan dalam perencanaan kegiatan siklus ini dengan tujuan untuk lebih meningkatkan dan menguatkan kemampuan guru dalam menyusun Rencana Pelaksanaan Pembelajaran(RPP) hingga bisa mencapai hasil minimal $70 \%$.

Pada akhir kegiatan siklus diperoleh hasil yang cukup menggembirakan yang memberikan indikasi tercapainya tujuan penelitian tindakan ini. Hasil yang diperoleh dapat kita lihat sebagai berikut: Perumusan tujuan pembelajaran hasil rata-rata menunjukkan angka $70 \%$. Pada penentuan bahan ajar diperoleh hasil $80 \%$,Penentuan strategi/metode pembelajaran ia dan alat mencapai $75 \%$ dengan variasi yang semakin beragam. Pada penentuan media dan alat pembelajaran ada peningkatan hingga 80\%, dan Perencanaan kegiatan evaluasi bisa mencapai $70 \%$ dan sudah mencantumkan, bentuk, jenis dan bahkan soal yang digunakan beserta kunci jawaban atau pedoman penilaiannya, serta mencantumkan alokasi waktu yang dibutuhkan.Grafik 3 menunjukkan kemampuan guru setelah siklus 2:

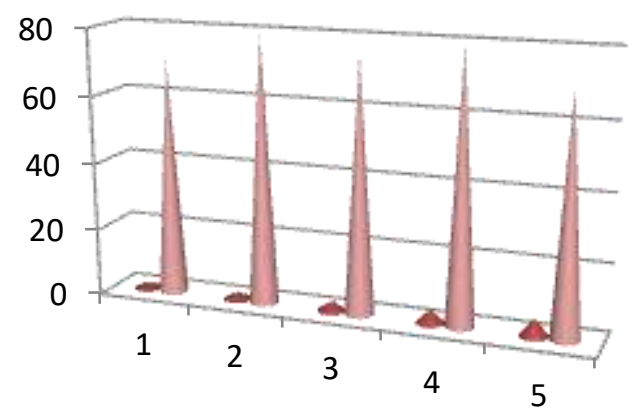

\section{Pembahasan}

\section{Grafik 3. Kemampuan Guru Setelah Siklus 2}

Dari data yang dikumpulkan sebelum dan selama proses penelitian tindakan, kita dapat melihat adanya peningkatan kemampuan guru pada masingmasing komponen perencanaan pembelajaran, sebagai berikut: 
1. Pada komponen Perumusan indikator tujuan pembelajaran, terlihat peningkatan dari $40 \%$ pada kemampuan awal, menjadi $60 \%$ pada siklus 1 dan meningkat menjadi $70 \%$ pada akhir kegiatan, seperti yang tampak pada grafik 4 berikut:

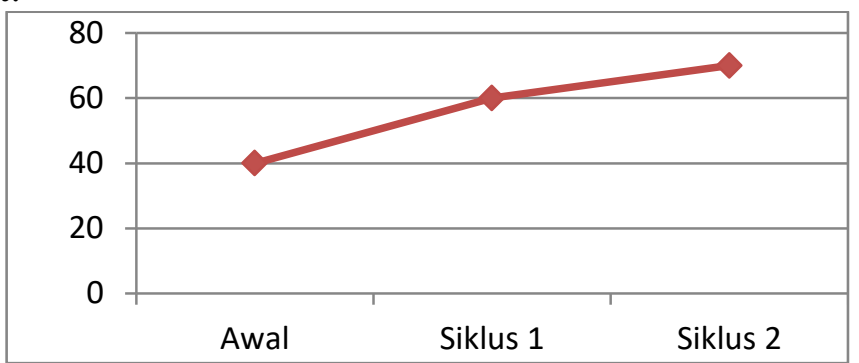

Grafik 4. Peningkatan kemampuan dalam Perumusan Tujuan Pembelajaran

2. Pada Komponen Penentuan bahan dan materi pembelajaran, terdapat peningkatan kemampuan dari $65 \%$ menjadi $70 \%$ setelah siklus 1 dan lebih menguat menjadi $80 \%$ setelah siklus 2 , untuk lebih jelasnya dapat kita lihat pada grafik 5 berikut:

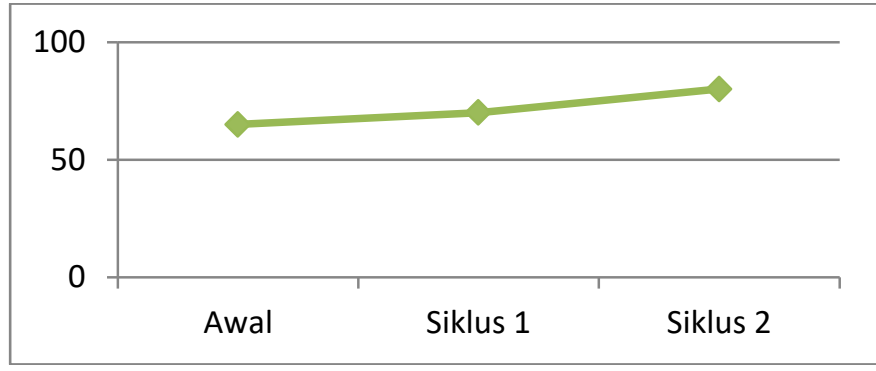

\section{Grafik 5. Peningkatan Kemampuan dalam Penentuan Bahan dan Materi Pembelajaran}

3. Dalam Komponen Pemilihan Strategi dan metoda pembelajaran, yang didalamnya memuat langkah-langkah pembelajaran dan penentuan alokasi waktu yang digunakan,terlihat adanya peningkatan yang signifikan dari yang semula hanya $40 \%$ menjadi $60 \%$ pada siklus 1 dan meningkat lagi menjadi 75\% setelah siklus 2 . Gambarannya dapat kita lihat pada grafik 6 berikut ini:

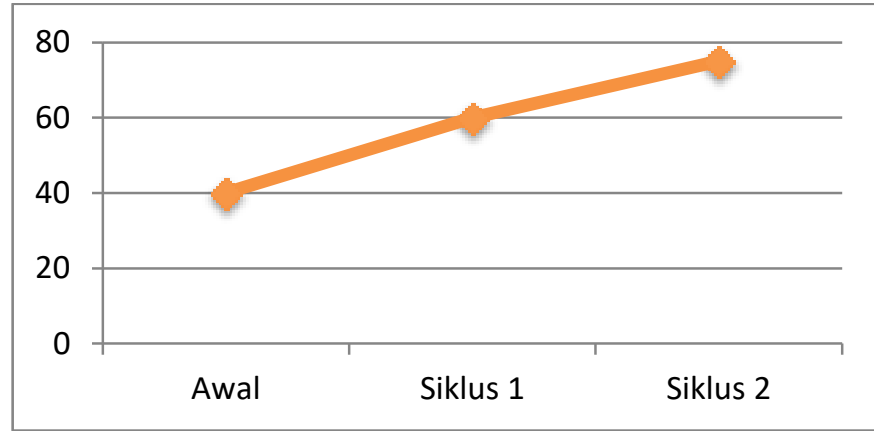

\section{Grafik 6. Peningkatan kemampuan dalam Penentuan Strategi dan Metode Pembelajaran}

4. Meskipun tidak terlihat adanya peningkatan yang cukup tajam, dalam komponen pemilihan Media dan alat pembelajaran juga terdapat adanya peningkatan dari $60 \%$ pada awal kegiatan dan setelah siklus 1 , menjadi $80 \%$ 
setelah siklus 2. Grafik 7 di bawah ini menunjukkan peningkatan kemampuan dalam pemilihan media dan alat pembelajaran.

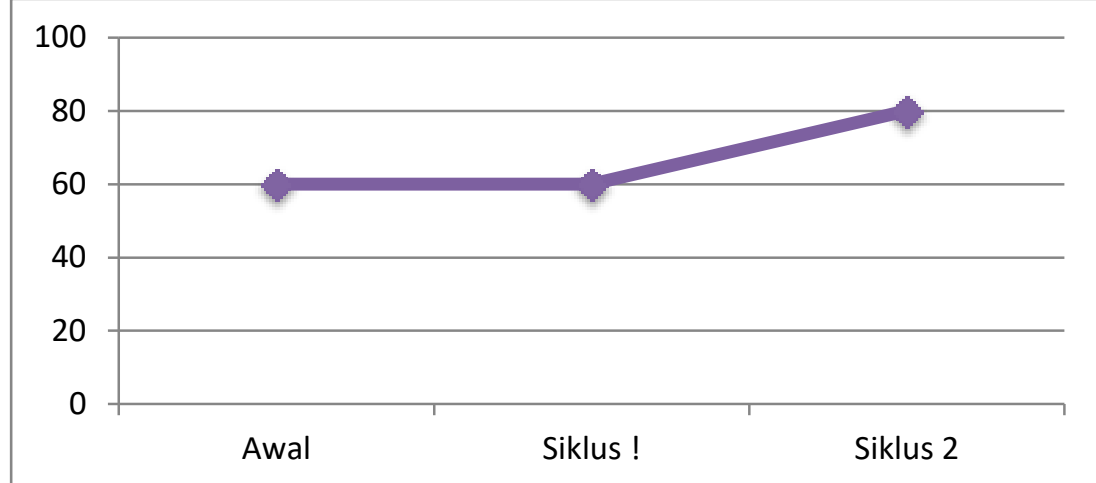

Grafik 7. Peningkatan Kemampuan dalam Pemilihan Media dan Alat Pembelajaran

5. Peningkatan yang cukup signifikan juga dapat kita lihat pada komponen perencanaan evaluasi pembelajaran. Dari yang semula hanya $40 \%$ pada awal kegiatan, menjadi $60 \%$ pada akhir siklus 1 dan berhasil mencapai $70 \%$ pada akhir siklus 2. Untuk lebih jelasnya kita dapat melihat gambarannya dalam grafik 8 berikut ini:

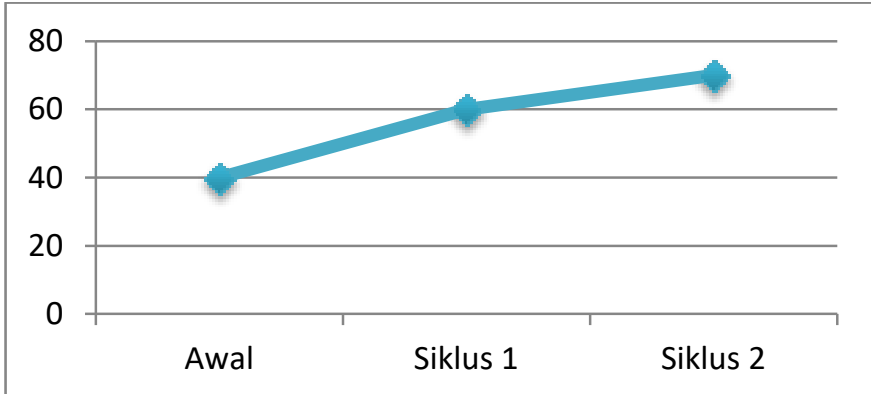

\section{Grafik 8. Peningkatan kemampuan dalam Perencanaan Evaluasi Pembelajaran}

Melihat data perolehan hasil penelitian dalam kegiatan penelitian tindakan sekolah ini, dapat disimpulkan bahwa supervisi direktif yang dilakukan oleh kepala sekolah terhadap 12 orang guru kelas, berhasil meningkatkan kompetensi pedagogik mereka dalam menyusun Perencanaan Pembelajaran. Hal ini dimungkinkan karena adanya kerja sama, motivasi dan bimbingan yang baik sehingga para guru memiliki antusiasme yang besar untuk dapat meningkatkan kemampuan mereka masing-masing dalam menyusun Rencana Pelaksanaan Pembelajaran (RPP) yang efektif.

\section{KESIMPULAN DAN SARAN}

Dari Proses Penelitian Tindakan sekolah yang dilakukan di SDN 01 Situjuah Batua yang berjudul Meningkatkan Kompetensi Guru dalam Penyusunan Rencana Pelaksanaan Pembelajaran melalui Supervisi Direktif dapat disimpulkan bahwa :

1. Pada komponen Perumusan indikator tujuan pembelajaran, terlihat peningkatan dari $40 \%$ pada kemampuan awal, menjadi $60 \%$ pada siklus 1 dan meningkat menjadi $70 \%$ pada akhir kegiatan. 
2. Pada Komponen Penentuan bahan dan materi pembelajaran, terdapat peningkatan kemampuan dari $65 \%$ menjadi $70 \%$ setelah siklus 1 dan lebih menguat menjadi $80 \%$.

3. Dalam Komponen Pemilihan Strategi dan metoda pembelajaran, yang didalamnya memuat langkah-langkah pembelajaran dan penentuan alokasi waktu yang digunakan,terlihat adanya peningkatan yang signifikan dari yang semula hanya $40 \%$ menjadi $60 \%$ pada siklus 1 dan meningkat lagi menjadi $75 \%$ setelah siklus 2 .

4. Meskipun tidak terlihat adanya peningkatan yang cukup tajam, dalam komponen pemilihan Media dan alat pembelajaran juga terdapat adanya peningkatan dari $60 \%$ pada awal kegiatan dan setelah siklus 1, menjadi $80 \%$ setelah siklus 2 .

5. Peningkatan yang cukup signifikan juga dapat kita lihat pada komponen perencanaan evaluasi pembelajaran. Dari yang semula hanya $40 \%$ pada awal kegiatan, menjadi $60 \%$ pada akhir siklus 1 dan berhasil mencapai $70 \%$ pada akhir siklus 2.

6. Melihat data perolehan hasil penelitian dalam kegiatan penelitian tindakan sekolah ini, dapat disimpulkan bahwa supervisi direktif yang dilakukan oleh peneliti terhadap 12 orang guru tersebut, berhasil meningkatkan kompetensi pedagogik mereka dalam menyusun Perencanaan Pembelajaran.

Saran yang dapat dikemukakan dari penelitian ini adalah:

1. Kegiatan supervisi direktif sangat baik dilakukan untuk membina guru meningkatkan kompetensinya. Sebaiknya kegiatan ini dilaksanakan secara terencana dan berkesinambungan.

2. Sebaiknya pembinaan ini dilanjutkan dengan supervisi direktif dalam pelaksanaan pembelajaran untuk mengukur kemampuan guru dalam mengimplementasikan rencana pembelajaran yang telah disusunnya.

3. Sebaiknya supervisi direktif juga dilakukan terhadap semua guru secara bergilir dan menyangkut seluruh aspek kemampuan/ kompetensi guru seperti yang disyaratkan dalam permendiknas no 16 tahun 2007.

\section{DAFTAR PUSTAKA}

Departemen Pendidikan dan Kebudayaan RI. 1982. Alat Penilaian Kemampuan Guru: Buku I. Jakarta: Proyek Pengembangan Pendidikan Guru.

1982. Panduan Umum Alat Penilaian Kemampuan Guru.Jakarta: Proyek Pengembangan Pendidikan Guru.

Alat Penilaian Kemampuan Guru: Hubungan antar Pribadi.Buku III. Jakarta: Proyek Pengembangan Pendidikan Guru.

. Alat Penilaian Kemampuan Guru: Prosedur Mengajar. Buku II. Jakarta: Proyek Pengembangan Pendidikan Guru.

Suhardjono, A. Azis Hoesein, dkk (1995). Pedoman penyusunan KTI di Bidang Pendidikan dan Angka Kredit Pengembangan Profesi Guru. Digutentis, Jakarta : Diknas

Suhardjono. 2005. Laporan Penelitian Eksperimen dan Penelitian Tindakan Kelas sebagai KTI, makalah pada Pelatihan Peningkatan Mutu Guru di LPMP Makasar, Juni 2005

Suhardjono. 2009. Tanya jawab tentang PTK dan PTS, naskah buku. 
Suharsimi, Arikunto. 2002. Penelitian Tindakan Kelas, Makalah pada Pendidikan dan Pelatihan (TOT) Pengembangan Profesi bagi Jabatan Fungsional Guru, 11-20 Juli 2002 di Balai penataran Guru (BPG) Semarang.

Suharsimi, Suhardjono dan Supardi. 2006. Penelitian Tindakan Kelas. Jakarta : PT Bumi Aksara

Supardi. 2005. Penyusunan Usulan, dan Laporan Penelitian Penelitian Tindakan Kelas, Makalah disampaikan pada "Diklat Pengembangan Profesi Widyaiswara", Ditektorat Tenaga Pendidik dan Kependidikan Dirjen Pendidikan Dasar dan Menengah, Departemen Pendidikan Nasional 